\title{
A Case Study of Education Master's Network Course Based on the AHP Method
}

\author{
Zixun Hua
}

\begin{abstract}
Chinese ministry of education carried out the pilot work about college graduate student degree educational comprehensive reform in 2010, as to encourage further reform and development of graduate education. Developing network course related to the ability of cultivating education master, help to improve the level of development of the education master in educational technology ability education reform. This study relies on the project of education master degree graduate education comprehensive reform in South China Normal University (SCNU). And use Analytic Hierarchy Process (AHP) what is a decision analysis method in combination of qualitative and quantitative research to construct an education master's network course Evaluation Index Model (EIM). According to the matrix calculations of the index weight, we put forward the network course development strategies. Under the guidance of the development strategies we have developed the network course "Modern educational technology" and applied this network course in the network learning process of education masters. Through the contrast test, we found that the network course "Modern Educational Technology" can improve autonomous learning information technology ability, improve the ability to adapt to changes in the development of information technology and media literacy in the process of autonomous learning.
\end{abstract}

Index Terms-Analytic hierarchy process, educational master, network course, development and applied research.

\section{BACKGROUND}

Interactive TV is a production of combine the digital TV technology and network technology. Developing the interactive digital educational television programs will help to improve the learners' learning initiative and creativity. ADDIE is a model of instructional systems design (ISD) [1], which has 5 stages that including analyze, design, development, implementation and evaluation. The model is applied to the curriculum or teaching system design general process and using ADDIE model at the design stage to ensure the effectiveness of the development process.

\section{A. Analytic Hierarchy Process}

The analytic hierarchy process (AHP), a simple and flexible multi-criteria decision-making method combining qualitative and quantitative analysis, was developed by professor T. L. Saaty who is one of the operational research experts in U.S. in the early 1970s. In recent years, AHP has been developed various forms, such as improve AHP(IAHP), fuzzy AHP(FAHP), extension FAHP and gray AHP(GAHP)

Manuscript received June 7, 2016; revised August 28, 2016.

Zixun Hua is with the College of Educational Information Technology, South China Normal University, Guangdong, Guangzhou 510631 China. He is also with College of Teaching and Learning, Ohio State University, Ohio State, Columbus 43202, USA (e-mail:252408933@qq.com).
[1].

\section{B. Educational Master of in Capacity-Building Network Courses}

The professional education of Master of Education degree is mainly course learning, and the courses should reflect its properties including disciplines, education and research. The scholar Walker (2009) proposed that the courses setting need to pay more attention to the ability of reflecting teaching practice and perfect theory of teaching skills [2]. To conclude it, the courses of Master of Education are not only necessary to attach importance of mastering theoretical knowledge, but also attach importance to use theories to analyze and solve practical problems [3]. According to the relevant state policies and regulations, the students of master of education mainly learn through the remote education and face-to-face teaching in summer and winter semesters [4].

There is quite a few research about the evaluation of network courses, but few of them are about master of education. These research usually focus on the network courses and ignore the role of teaching objects-students.

Scholar Guo (2009) raised evaluation table of Network teaching design. Li (2004) point out nine dimensions of the network curriculum evaluation. Professor $\mathrm{Xu}$ Fuyin and professor Li Yunlin propose five properties of network courses evaluation including instruction, science, technique, art and application [5]. Among these study, it is found that the evaluation procedure is not standard and rarely combine quality and quantity evaluation well. It could influence the reliability and validity of network course evaluation study in a way. It is also difficult to evaluate, monitor and manage the quality of network courses effectively [6].

\section{The Research Status of AHP Applied to Network Course Evaluation}

Evaluation of network courses should try to avoid too much subjectivity and arbitrariness [7]. There are some disadvantages using AHP to evaluate network courses. Through AHP, the quantized value of network course evaluation is obtained, which could evaluate network courses intuitively on the whole and make it practical to evaluate several network courses [8]

Sipahi (2010) determined the quality factor hierarchical model of network course using AHP and calculated the initial weights of the various evaluation. With these efforts, four evaluative dimensions came into being, which was instructional design, Course content, interface design, and technical property [9]. H. William (2008) stroke a network enhanced teaching evaluation index weights with a combination of AHP and Delphi, which was the reasonable use of the expert's experience, insight and intuition, and overcame the influence of subjectivity of the experts to make 
sure that weights of each index entry were scientific and reasonable [10]. In conclusion, these studies tried to integrate AHP with Delphi in order to put forward complete network courses evaluation index system, standardize and guide the quality evaluation of the courses, which will lead to design and develop network courses.

\section{RESEARCH QUESTIONS}

According to the research status above, researcher found:

At present, there is still no network course evaluation index system for master of education. In the actual process of research, researcher can develop evaluation index system based on the characteristic of students in master of education and then develop network course based on the evaluation index system.

Researcher not only get the weights of evaluation index system using AHP, but also develop network course with the guidance of these weighs. However, quite few researchers learn from this thinking in the development of network course.

In the process of application, evaluation questionnaire is needed. But for these study nowadays, it is generally terminated, but not perfect the effectiveness of evaluation index system.

\section{Methodology}

Development of network course evaluation index system of master of education contains getting evaluation index and determining the relationship between each index.

\section{A. Evaluation Index}

In order to find out the quality of network course of master of education, researcher chose five students to carry on an interview. From this interview, researcher cramped out more than 150 items of evaluation index. This study also refers to several evaluation index systems of network course, especially those which are helpful for our study.

From all these evaluation indexes, there are 21 items of evaluation indexes been collected as third-level indicators. And then we analyzed and summarized them into seven secondary indicators, including instruction design, teaching specification, interaction design, interaction content, technical support, technical adaptation and design style. At last, researcher summarized these seven indicators into three first-level indicators which were educational property, interactive property and technical property. After this process designer has formed three-level index system of network course of master of education.

\section{B. Calibration Value of Index}

Because AHP has both the characteristic of qualitative and quantitative research, researcher could carry on a subjective evaluation, and meanwhile, researcher calculated index weight. In this study, designer designed an enquiry scale of evaluation index weight. Then researcher went on pairwise comparisons of indicators and divide importance degree of comparisons into five levels. The first level indicates two indicators are equally important, the second level represents the left indicator is a little important than the right one, the third level indicates the left indicator is more important that the right one, the fourth indicates the left indicator is rather more important than the right one, and the fifth level indicates the left indicator is much more important than the right one. Otherwise, if people under investigation think that the right indicator is more important than the left one, they need to write the inverse value in the corresponding table.

For example, when compare interactive property with technical property, someone considers interactive property is a little important than technical property, which is equal to 2 . On the contrary, the calibration value is $1 / 2$.

Researcher gave out 57 questionnaires about enquiry scales of evaluation index weight to master of education students and collet all of them. Among them, there were 54 questionnaires effective, which represented $91.9 \%$ effective rate. Then can calculated each index weight from these questionnaires.

\section{Constructing Pairwise Comparison Matrix}

When calibration value of pairwise comparison of each index was determined, the comparison matrix of three-level index was constructed. Each calibration value was aij, and its corresponding calibration value in diagonal line was 1/aji.

For example, as educational, interactive and technical property in pairwise comparison and calculate average of these calibration values. Finally, researcher build the matrix of the first level indicator enquiry scale which is called positive reciprocal matrices (Table I).

TABLE I: PositIVE RECIPROCAL MATRICES OF THE FIRST LEVEL

\begin{tabular}{|c|c|c|c|}
\hline & V1 & V2 & V3 \\
\hline V1 & 1 & 1 & 2 \\
\hline V2 & 1 & 1 & 3 \\
\hline V3 & 0.5 & 0.3333 & 1 \\
\hline
\end{tabular}

\section{Calculating Index Weight}

There are some research methods to calculate index weight, such as standardized column average method, square root method, power multiplication method and so on. In the study, researcher chose the standardized column average method. Firstly, researcher calculated the sum of each column in the pairwise comparison matrix. The sum formula is $\mathrm{Aij}=\sum_{j=1}^{i} a \mathrm{ij}$. Then each element was divided by the sum of each column in order to get a new matrix called standard pairwise comparison matrix. The process could show that the formula was $\mathrm{Bij}=1 / \mathrm{Aij}$ and the result is as follow (Table II).

TABLE II: STANDARD PAIRWISE COMPARISON MATRIX
\begin{tabular}{|c|c|c|c|}
\hline & V1 & V2 & V3 \\
\hline V1 & 0.4 & 0.4292 & 0.3333 \\
\hline V2 & 0.4 & 0.4292 & 0.5 \\
\hline V3 & 0.2 & 0.1416 & 0.1667 \\
\hline
\end{tabular}

After calculating average of each column in standard pairwise comparison matrix, the feature vector of first-level indicator matrix was constructed. Feature vector W1 was indicator weight of three indicators, $\mathrm{W} 1=[0.39,0.44,0.17]$. Therefore, the index weight calculation process could be 
concluded as $\mathrm{Wi}=\mathrm{aij} / \sum_{j=1}^{i} a \mathrm{ij}$

\section{E. Consistency Test}

To test consistency of matrix, researcher has to test consistency of all the feature vectors through the formula $\mathrm{CI}=$

$(\lambda \max -n) /(n-1)$. While $\lambda$ max was equal to $n$, the value of CI was 0 , which indicated that the feature vectors were consistent. So the larger CI was, the worse the consistence was. It needed to add a correction value $\mathrm{RI}$, then the consistence indicator was changed as $\mathrm{CR}=\mathrm{CI} / \mathrm{RI}$.

TABLE III: CORRECTION VALUE
\begin{tabular}{|l|l|l|l|l|l|l|l|l|l|}
\hline$n$ & 1 & 2 & 3 & 4 & 5 & 6 & 7 & 8 & 9 \\
\hline $\mathrm{RI}$ & 0 & 0 & 0.58 & 0.9 & 1.12 & 1.24 & 1.32 & 1.41 & 1.45 \\
\hline
\end{tabular}

Take the consistence test of the first-level indicators for example, firstly, the tested pairwise comparison matrix was multiplied by the feature vector to gain empowerment and vector like the following equation:

$$
\left[\begin{array}{ccc}
1 & 1 & 2 \\
1 & 1 & 3 \\
0.5 & 0.33 & 1
\end{array}\right] *\left[\begin{array}{l}
0.39 \\
0.44 \\
0.17
\end{array}\right]=\left[\begin{array}{l}
1.17 \\
1.34 \\
0.52
\end{array}\right]
$$

Secondly, weights of each empowerment and vector were divided by weights of feature vector. Then, researcher calculated the average $\lambda \max$, and the calculating formula could be $\lambda \max =(3+3.05+3.06) / 3=3.04$.

Lastly, designer continued to calculate the consistence indicator CI with the formula $\mathrm{CI}=(\lambda \max -\mathrm{n}) /(\mathrm{n}-1)=(3.04-3) /$ $(3-1)=0.02$. And the consistency rate would be $\mathrm{CR}=\mathrm{CI} / \mathrm{RI}=0.02 / 0.58=0.034<0.01$. Therefore, researcher got the result that it met the consistence requirement and the corresponding feature vector is efficient.

\section{F. Establish Index Weight}

With these calculating process above, researcher obtained weights of all three-level indicators in the evaluation index system of network course.

TABLE IV: WEIGHTS OF EVALUATION INDEX SYSTEM

\begin{tabular}{|c|c|c|c|}
\hline 评价目标 V & 一级指标 $V_{i}$ & 二级指标 $V_{i i}$ & 三级指标 $V_{i i i}$ \\
\hline \multirow{21}{*}{$\begin{array}{l}\text { 教育硕士 } \\
\text { 网络课程 } \\
\text { 质是 } \mathrm{V}=1\end{array}$} & \multirow{6}{*}{$\begin{array}{l}\text { 教 育 性 } \\
V_{1}=0.58\end{array}$} & \multirow{3}{*}{$\begin{array}{l}\text { 教学 设 计 } \\
V_{11}=0.74\end{array}$} & 教学目标 $V_{111}=0.49$ \\
\hline & & & 教学方法 $V_{112}=0.32$ \\
\hline & & & 教学对象 $V_{113}=0.19$ \\
\hline & & \multirow{3}{*}{$\begin{array}{l}\text { 教 学 规 范 } \\
V_{12}=0.26\end{array}$} & 理论规范 $V_{121}=0.45$ \\
\hline & & & 实践规范 $V_{122}=0.35$ \\
\hline & & & 媒体选用 $V_{123}=0.2$ \\
\hline & \multirow{6}{*}{$\begin{array}{l}\text { 交 互 性 } \\
V_{2}=0.28\end{array}$} & \multirow{3}{*}{$\begin{array}{l}\text { 交 互 设 计 } \\
V_{21}=0.65\end{array}$} & 模块设计 $V_{211}=0.48$ \\
\hline & & & 导航策略 $V_{212}=0.31$ \\
\hline & & & 交互功能 $V_{213}=0.21$ \\
\hline & & \multirow{3}{*}{$\begin{array}{l}\text { 交互内容 } \\
V_{22}=0.35\end{array}$} & 交互资源 $V_{221}=0.48$ \\
\hline & & & 资源类型 $V_{222}=0.25$ \\
\hline & & & 内容定位 $V_{223}=0.23$ \\
\hline & \multirow{9}{*}{$\begin{array}{l}\text { 技 术 性 } \\
V_{3}=0.14\end{array}$} & \multirow{3}{*}{$\begin{array}{l}\text { 技术支接 } \\
V_{31}=0.48\end{array}$} & 软件支接 $V_{31}=0.49$ \\
\hline & & & 硬件支接 $V_{312}=0.28$ \\
\hline & & & 性能稳定 $V_{313}=0.23$ \\
\hline & & \multirow{3}{*}{$\begin{array}{l}\text { 技术适用 } \\
V_{32}=0.32\end{array}$} & 实践需要 $V_{321}=0.55$ \\
\hline & & & 绕效需要 $V_{322}=0.28$ \\
\hline & & & 媒介兼容 $V_{323}=0.17$ \\
\hline & & \multirow{3}{*}{$\begin{array}{l}\text { 设计 风格 } \\
V_{33}=0.19\end{array}$} & 界面设计 $V_{\mathrm{g} 1}=0.5$ \\
\hline & & & 设计风格 $V_{932}=0.29$ \\
\hline & & & 模块布局 $V_{393}=0.21$ \\
\hline
\end{tabular}

As a total score with 100 points, researcher assigned scores according to weight of each index. The result was shown in
Fig. 1, 2, 3 .

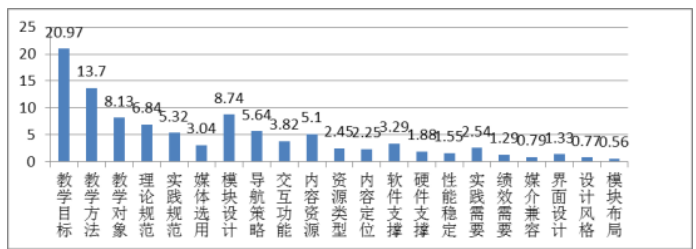

Fig. 1. Weight distribution of the third-level indicators.

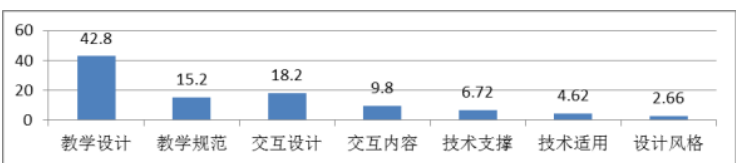

Fig. 2. Weight distribution of the second-level indicators.

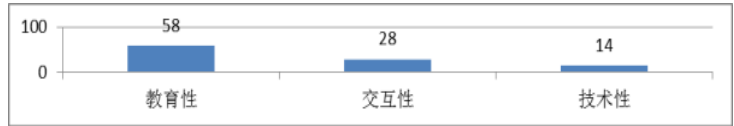

Fig. 3. Weight distribution of the first-level indicators.

\section{RESEARCH PROCESS}

According to the evaluation index system based on the AHP method to construct index weight, researcher can conclude that the relative important indicators to evaluate the network courses pros and cons. Educational is the most important indicator in the evaluation index system and came next is interactive. In educational, instructional design is the most important secondary indicator.

\section{A. The Development Strategy of the Master of Education Network Course}

Regardless of what form of educational resources or learning resources are required to meet the general law as it applies to the educational process. This requirement researcher should be combined with the characteristics of their learning and development courses training requirements in the process to applied the Master of Education Network courses. In summary, designer conclude that the 4-point Master of Education network course construction ideas:

- Three-dimensional resources.

Development network courses will provide teaching resources and cases of various forms of media. The resources could achieve the purpose of preferences to choose according to their individual needs and forms of media.

- Modular structure.

The content of network course will be presented by modular structure. This kind of course structure is clear and well-structured chapters

- Practice-oriented.

The network course will provide a large number of teacher video lessons and teaching design cases to building the practical ability of the Master of Education.

- Case-oriented.

The network course will make the Master of Education to recognize the real environment of the primary and secondary teaching by video cases. The video cases will provide an initial understanding and practical guidance for the Master of Education to participate in the teaching process in the future.

B. Development the "Modern Educational Technology" Master of Education Network Course

The This study relies on the key commissioned projects 
which is called "Master of Education Degree comprehensive reform" to digitize construction related courses of the Master of Education in South China Normal University. The study group selected the "Modern Educational Technology" Master of Education course written by Xu Fuyin as the development course. According to the section of "Modern Educational Technology" researcher have rebuilt this course. The development process including 4 parts:

- Development the expert teaching video lessons of the course "Modern Educational Technology".

- Development the teachers share sub-disciplines lessons of the course "Modern Educational Technology".

- Development the instructional design cases of the course "Modern Educational Technology".

- Collected and integrated the disciplinary applications resource tools of the course "Modern Educational Technology".

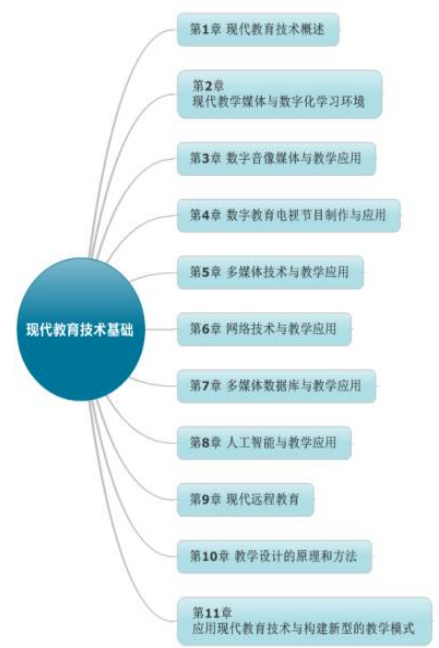

Fig. 4. The course construction of "Modern Educational Technology".

"Modern Educational Technology" course has combines theory and practice of educational technology in the teaching process, which provides a wealth of practical guidance for the Master of Education into the teaching process. And this course is also could solved the teaching dilemma of how to use technology in the teaching process?

According to the demand of the courses information rebuilt for the Master of Education researcher have selected the 11 chapters of the course "Modern Educational Technology". Researcher have developed a total of 23 experts teaching video lessons and these video lessons are shot by expert speakers.

In the part of teachers share video cases, researcher have developed the video cases on basis of the courses "Modern Educational Technology". Meanwhile, researcher will develop the video cases based on the different disciplines. The teachers of video cases will include multi-science teachers of all grades of the primary and secondary. This kind of video cases will to facilitate students` practical guidance.

In the part of the collet and integrate of the discipline application resources tool, researcher will collect the resources on the basis of the courses "Modern Educational Technology". On average, it has 1-3 resource tool each chapter.

\section{The "Modern Educational Technology" Master of Education Network Course}

The network course which developed by research group has including all kind of resources that have been collected and integrated. The resources including: expert video lessons, teachers share cases, instructional design cases and the discipline application resources tool. These resources will give the facilitate to students to use the network access to course resources and expand students` learning, meanwhile have finished the construction and improvement for the courses "Modern Educational Technology".

In the part of teaching and management of network course, researcher have developed the master of education network course "Modern Educational Technology" which was developed based on the master of education course "Modern Educational Technology", and there are four modules including "lead by experts", "lesson appreciation", "case study" and "discipline tool".

The module "lead by experts" is the expert video lessons of "Modern Educational Technology" which are including the whole teaching content of the eleven sections of the course. The module "lesson appreciation" is the teachers share video cases of "Modern Educational Technology" which are divided in eleven modules on the basis of the eleven sections. These eleven modules have covered a number of primary and secondary schools teaching subjects. The module "case study" is the instructional design cases of "Modern Educational Technology" which have been gave the help for the learning of students. The module "discipline tool" is the discipline application resources tool of "Modern Educational Technology", and the tools have different application in the teaching process.

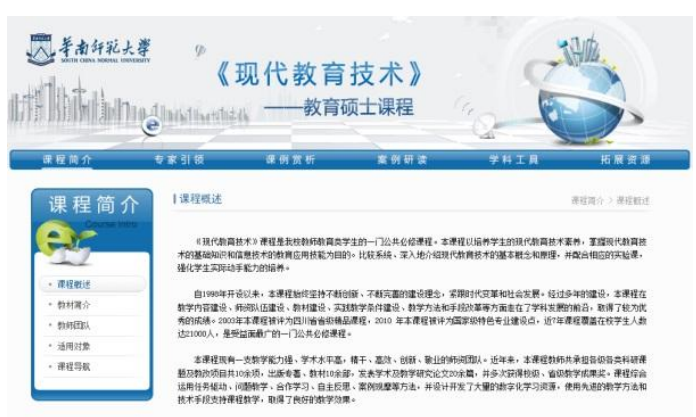

Fig. 5. The module of the course "Modern Educational Technology".

There are also eleven sections teaching contents in the four modules, and these eleven sections including "Modern Educational Technology Overview", "Modern teaching media and digital learning environment", "Digital audio-visual media and teaching applications", "Television program production and application of digital education", "Multimedia technology and teaching", "Network technology and teaching", "Multimedia database and teaching applications", "Artificial Intelligence and teaching", "Modern Distance Education", "Instructional design principles and methods" and "Application of modern educational technology and build a new teaching mode".

\section{Evaluation}

\section{A. Research Purposes and Hypotheses}


The purpose of this study is to verify the effectiveness of the network course "Modern Educational Technology", and researcher thought that this network course will improve the professional competence of the Master of Education. The network course has been developed by the Evaluate index system which was constructed by the theory of Analytic Hierarchy Process. So designer thought that this study has certain forward-looking. But the designer of this paper need to conduct research to the master of education who have learning this network course, the purpose is to verify the effectiveness of the network course.

The hypothesis of this study is the network course "Modern Educational Technology" has effectively promoted the professional competence of the Master of Education.

\section{B. Evaluation Process}

The research method of this study is questionnaire. Researcher have invented 22 master of education to evaluate the quality of the network course "Modern Educational Technology". There are 4 steps of this research process:

- Introduced of the background and purpose of this study to the survey, and describes the use of the network course for master of education.

- Let the survey have self-learning and collaborative learning by use the network course.

- Let the survey to fill out the Network Course Quality Assessment Scale of "Modern Educational Technology" in a week later.

- To analysis the data of the questionnaire.

\section{Data Analysis}

TABLE V: VOLUNTEER STATISTICS ON NETWORK QUALITY OF THE COURSE EVALUATION RESULTS

\begin{tabular}{|c|c|c|c|c|c|c|c|c|}
\hline \multirow{2}{*}{$\begin{array}{l}\text { 一级 } \\
\text { 指标 }\end{array}$} & \multirow{2}{*}{$\begin{array}{l}\text { 二 级 } \\
\text { 指标 }\end{array}$} & \multirow[t]{2}{*}{ 三级指标 } & \multicolumn{4}{|c|}{ 评价等级 } & \multirow[t]{2}{*}{$\mathrm{Wi}$} & \multirow[t]{2}{*}{$\mathrm{Fi}$} \\
\hline & & & 优 & 良 & 中 & 差 & & \\
\hline \multirow{6}{*}{$\begin{array}{l}\text { 教 育 } \\
\text { 性 }\end{array}$} & \multirow{3}{*}{$\begin{array}{l}\text { 教 学 } \\
\text { 设计 }\end{array}$} & 学习目标 & 16 & 5 & 1 & 0 & 0.92 & 19.32 \\
\hline & & 学习方法 & 7 & 14 & 1 & 0 & 0.82 & 11.48 \\
\hline & & 学习对象 & 10 & 11 & 1 & 0 & 0.84 & 6.72 \\
\hline & \multirow{3}{*}{$\begin{array}{l}\text { 教 育 } \\
\text { 规范 }\end{array}$} & 理论规范 & 12 & 8 & 2 & 0 & 0.86 & 6.05 \\
\hline & & 实践规范 & 14 & 6 & 2 & 0 & 0.89 & 4. 43 \\
\hline & & 媒体选用 & 10 & 11 & 1 & 0 & 0.85 & 2. 56 \\
\hline \multirow{6}{*}{$\begin{array}{l}\text { 交 互 } \\
\text { 性 }\end{array}$} & \multirow{3}{*}{$\begin{array}{l}\text { 交 互 } \\
\text { 设计 }\end{array}$} & 模块设计 & 7 & 10 & 1 & 0 & 0.68 & 5.45 \\
\hline & & 导航策略 & 14 & 8 & 0 & 0 & 0.91 & 5.45 \\
\hline & & 交互功能 & 11 & 7 & 4 & 0 & 0.83 & 3. 32 \\
\hline & \multirow{3}{*}{$\begin{array}{l}\text { 交互 } \\
\text { 内容 }\end{array}$} & 交互资源 & 11 & 10 & 1 & 0 & 0.86 & 4. 32 \\
\hline & & 资源类型 & 11 & 11 & 0 & 0 & 0.88 & 2.63 \\
\hline & & 内容定位 & 13 & 9 & 0 & 0 & 0.90 & 1.80 \\
\hline \multirow{9}{*}{$\begin{array}{l}\text { 技术 } \\
\text { 性 }\end{array}$} & \multirow{3}{*}{$\begin{array}{l}\text { 技术 } \\
\text { 支接 }\end{array}$} & 软件支墇 & 11 & 11 & 0 & 0 & 0.88 & 2.63 \\
\hline & & 硬件支接 & 13 & 8 & 1 & 0 & 0.89 & 1.77 \\
\hline & & 性能稳定 & 12 & 8 & 2 & 0 & 0.86 & 1.73 \\
\hline & \multirow{3}{*}{$\begin{array}{l}\text { 技术 } \\
\text { 适用 }\end{array}$} & 实践需要 & 11 & 10 & 1 & 0 & 0.86 & 2.59 \\
\hline & & 绩效需要 & 14 & 7 & 1 & 0 & 0.90 & 0.90 \\
\hline & & 媒介兼容 & 14 & 7 & 1 & 0 & 0.90 & 0.90 \\
\hline & \multirow{3}{*}{$\begin{array}{l}\text { 设 计 } \\
\text { 风格 }\end{array}$} & 界面设计 & 12 & 8 & 2 & 0 & 0.86 & 0.86 \\
\hline & & 设计风格 & 10 & 11 & 1 & 0 & 0.85 & 0.85 \\
\hline & & 模块布局 & 15 & 7 & 0 & 0 & 0.92 & 0.92 \\
\hline
\end{tabular}

With the index system of network course quality evaluation constructed by designer, researcher went on to make an investigation and our research assumption that the network course" Modern Educational Technology" made a good effect. In our experiment, researcher gave out 22 questionnaires to the volunteers. The questionnaires were divided into four evaluation levels including "excellent", "good", "medium" and "poor". And then, based on these questionnaires, researcher analyzed and calculated scores of every index and overall score of the program quality.

According to the formula of scoring average $\mathrm{Wi}=\left(\sum\right.$ $($ ai $\times n)) /(a h \times N)$. Researcher made Wi multiplied the weight of every index in order to get the scores of every index. In the formula, "ai" is the score of every level, "ni" is the population, ah is the highest score and $\mathrm{N}$ is the total population.

For aspect of Instructive, many people thought that the network course "Modern Educational Technology" quality level was "excellent" for the indexes of learning objectives, theory specification and practice specification. And the indexes of learning methods, learning objects and media selection were just "good". This is proof that the network courses need provide the learning content that will meet the learner characteristics.

For aspect of interactive, the index of navigation strategies, interactive function and content locating quality was "excellent". There are some people thought that the indexes of module design is "good". This was demonstrated the network course must to make the combine between teach and interact.

For aspect of technical, the index of hardware support, stable performance, practice requirement, performance requirement, media compatibility, interfacial design and module layout was "excellent". This is proof that the network courses have achieved the purpose of use the interactive technology. But some people thought that the index of design style was just "good". Researcher could found that this network course has not satisfied the art need of some students, so researcher should make the network course more beautiful.

Researcher gained the score of every index after the statistics of questionnaire evaluation. With these work done, researcher calculated the establishment quality of the network course "Modern Educational Technology" that was Fi equal to 86.68. According to the levels, the poor level is below 60scores, the medium is between 61 and 75 scores, the good level is between 76 and 85 scores, and the excellent level is more than 86 scores. So researcher made a conclusion that this network course quality was excellent.

\section{CONCLUSION}

During the research process, researcher can give the conclusion that can reflect research questions of this paper:

1) The network course based on AHP is a good example for China's master education. On one hand, it has provided an example for how to design, develop, evaluate the education master's network course. On the other hand, this research also given an example for AHP theory that it can be applied for educational masters. For details is that the Fi value of this case study has got a score of 86.68 .

2) This research give the AHP method different apply situation that not only it is a method to establish an evaluate system, but also is a guideline to design and develop a network course. For example, the index of this research are not only the evaluate index, but also can guide the design and develop process of the research process.

3) Meanwhile, the Master of Education related courses 
were developed in the form of network have achieved the personalized learning and interactive learning for student. For the three index can get a high score, that's means the educational masters indeed can get the improvement during this process.

Finally, for the later research, researcher will focus on the development and application of the Master of Education courses resources, this will provide references and ideas to development for the Master of Education relate curriculum.

\section{ACKNOWLEDGMENT}

This research would thank for the help of the teachers X. W. Li, X. Y. Lin, and the students who participated in this research. In addition, the researcher would gratefully acknowledge the help and support by professors F. Y. Xu, P. $\mathrm{Z}$. Wu and X. Y. Hu.

\section{REFERENCES}

[1] J.-Y., Guo, Z.-B. Zhang, and Q.-Y. Sun, "Study and applications of analytic hierarchy process," China Safety Science Journal (CSSJ), vol. 5, 2008, p. 26.

[2] W. Andrew and H. Leary, "A problem based learning meta analysis: Differences across problem types, implementation types, disciplines, and assessment levels," Interdisciplinary Journal of Problem-Based Learning, vol. 3, no.1, 2009, p. 6.

[3] M. M. B. Baxter and P. M. King, "Learning partnerships: Theory and models of practice to educate for self-authorship," Stylus Publishing, LLC., 2004.

[4] F. Julio et al., "Health professionals for a new century: Transforming education to strengthen health systems in an interdependent world," The Lancet, vol. 376, no. 9756, 2010, pp. 1923-1958.
[5] L.-J. Guo et al., "Criticality evaluation of petrochemical equipment based on fuzzy comprehensive evaluation and a BP neural network," Journal of loss Prevention in the Process Industries, vol. 22, no. 4, 2009, pp. 469-476.

[6] W. Li et al., "Study of the index system for assessing interactive qualities of web-based courses," Open Education Research, vol. 6, 2004, p. 12

[7] Z.-A. Zhang and Y.-B. Li, "Comprehensive evaluation of network-based courses based on the analytical hierarchy process: A case study of instructional design network-based course," China Medical Education Technology, vol. 1, 2009, pp. 64-65.

[8] S. V. Omkarprasad and S. Kumar, "Analytic hierarchy process: An overview of applications," European Journal of Operational Research, vol. 169 , no.1, 2006, pp. 1-29.

[9] S. Seyhan, and M. Timor, "The analytic hierarchy process and analytic network process: an overview of applications," Management Decision, vol. 48 , no.5, 2010, pp. 775-808

[10] H. William, "Integrated analytic hierarchy process and its applications - A literature review," European Journal of Operational Research, vol. 186 , no. 1,2008 , pp. 211-228.

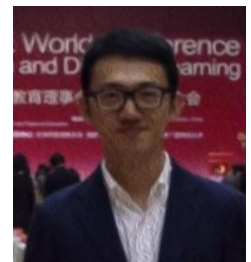

Zixun Hua was born in Chaoyang, Liaoning province, China in 1987. He received his B.Sc. and M.Sc. degrees in 2006 and 2014 respectively from the East China Jiaotong University and South China Normal University. Now, he is study for Educational technology`s Ph.D. degree in SCNU.

During the studying process, he has published some papers about e-learning resources, like "The development and application research of education master's network course based on the analytic hierarchy process" on the $25^{\text {th }}$ ICDE world conference for Open Distance Education, and "the design research based on the interactive navigation process for interactive educational television program" on the 2012 Chinese International conference for Educational technology. His research interests focus on educational television, MOOCs, SPOCs, and flipped classroom. 